\title{
ÁRAMLÁS- ÉS HÖTECHNIKAI FEJLESZTÉSEK AZ EFOP-3.6.1 PROJEKT KERETÉBEN
}

\author{
Bencs Péter \\ egyetemi docens, intézetigazgató, Miskolci Egyetem, Energetikai és Vegyipari Gépészeti Intézet, \\ Aramlás- és Hötechnikai Gépek Intézeti Tanszék \\ 3515 Miskolc, Miskolc-Egyetemváros, e-mail: arambp@uni-miskolc.hu
}

\section{Faragó Dávid}

doktorandusz, Miskolci Egyetem, Energetikai és Vegyipari Gépészeti Intézet, Áramlás- és Hötechnikai Gépek Intézeti Tanszék

3515 Miskolc, Miskolc-Egyetemváros, e-mail: aramfd@uni-miskolc.hu

\author{
Mohammed Alktranee \\ doktorandusz, Miskolci Egyetem, Energetikai és Vegyipari Gépészeti Intézet, \\ Áramlás- és Hötechnikai Gépek Intézeti Tanszék \\ 3515 Miskolc, Miskolc-Egyetemváros, e-mail: aramma@uni-miskolc.hu
}

\begin{abstract}
Absztrakt
Jelen összefoglaló mü célja bemutatni az EFOP 3.6.1. projekt idöszakában zajló kutatásokat. Kutatás egyik iránya az anizotrop turbulencia-intenzitások vizsgálata, elsösorban a Reynolds-feszültségek és az energiaspektrumok négyzet keresztmetszetü csatornában történö eloszlásának vizsgálata, anizotróp turbulens légáramlást elöidézö félig aktív sugár-turbulencia rács mögött. A kutatás másik iránya a napenergia-rendszerek különbözö alkalmazásokban történö felhasználását vizsgálja a legmegfelelöbb rendszer meghatározása érdekében, amely rendkivül hatékony és megbizható. A hibrid szolár / termikus rendszerek hatékonynak bizonyultak a szükséges villamosenergia-terhelések kielégitésére, és jó kapacitással voltak képesek egyszerre termikus energiát biztositani károsanyag kibocsátás nélkül.
\end{abstract}

Kulcsszavak: turbulencia, mérés, határréteg, PV/T, nano folyadék

\begin{abstract}
This summary work aims to present the EFOP 3.6.1. research during the project period. One direction of research is to investigate anisotropic turbulence intensities, id est to investigate the distribution of Reynolds stresses and energy spectra in a square cross-section channel, downstream of a semi-active jet turbulence grid generating anisotropic turbulent airflow. In addition to the semi-active jet turbulence grid, another type of turbulence grid was developed and experimentally investigated. The second direction of research investigates the uses of solar energy systems in various applications to define the most appropriate system that has highly efficient and reliable. hybrid solar/thermal systems had proven effective to meet the required loads of electric energy and good capacity to provide thermal energy simultaneously without toxic emissions.
\end{abstract}

Keywords: turbulence, measurement, boundary-layer, PV/T, nanofluid 


\section{Bevezetés}

\subsection{Turbulencia}

Különböző típusú turbulencia-rácsok léteznek (aktív, passzív, félaktív stb.), Amelyek megkönnyítik a laboratóriumi szélcsatornákban a megfelelő turbulencia létrehozását. Ezeket a rácsokat általában a szélcsatorna mérési szakasza előtt helyezik el a megfelelő áramlási paraméterek előállítása érdekében. Vizsgálatok történhetnek ott, ahol az alap légáramlás már turbulens, ilyenkor a turbulencia rácsok felhasználhatók a turbulens tulajdonságok, például a turbulens mozgási energia javítására. A passzív turbulencia rács egy nem mozgó rács, amelyet egy szélcsatornában helyeznek el. Általános dinamikus értelemben azonban aktív rácsoknak is tekinthetők [1]: pl. a határrétegen belüli rétegek bizonytalan mozgásokkal rendelkeznek. Az izotróp turbulencia vizsgálatában az első (valószínüleg [2]), amely több évtizeddel korábban kezdődött, egy turbulenciát generáló rács passzív formájában történt. A kontrakció szerepét a passzív rács által kiváltott turbulencia izotropiájában Comte-Bellot \& Corrsin [3] vizsgálta. A rácskísérleteknél valószínűleg a legfontosabb a Comte-Bellot publikációja [4]. A rács által generált turbulencia áramlásmérései a turbulencia elmélet legfontosabb kísérletei, amelyek megfelelő határfeltételeket és megfelelő adatokat szolgáltatnak a turbulencia modellek validálásához. A rács Reynolds-száma (vagy Taylor Reynolds-száma) a passzív rács méreteitől és nagyrészt a generált turbulenciától függ [5]. Fontos megemlíteni, hogy az aktív rácsokkal végzett kísérletek, amelyek megkönnyítik a határok mozgatását ([6] rezgő rácsok), vagy olyan rácsok, amelyek képesek növelni az áramlás átlagos impulzusát, az utóbbi évtizedekben egyre hangsúlyosabbá váltak [7].

Ezen túlmenően az aktív rácsok között ígéretes lehetőségek rejlenek azok a turbulencia rácsok, amelyeket "sugár rács" neveznek, és amelyek másodlagos sugárzásokon keresztül változtatják az átlagos áramlási sebességet. A sugár rácsok nagy intenzitású turbulenciát generálnak, és ezzel egyidejűleg képesek fenntartani a megfelelő homogenitási szintet. Ez magasabb Reynolds-számokat eredményez, és ezáltal megvalósíthatóvá teszi a meglévő kísérletek bővítését [8]. A bemutatott munka motivációja egy szinte homogén áramlás elérése volt, közepes átlagos sebességgel $(\mathrm{kb} .3 \mathrm{~m} / \mathrm{s})$ és viszonylag magas turbulens mozgási energiával (kb. $\left.0,5 \mathrm{~m}^{2} / \mathrm{s}^{2}\right)$, ami a meteorológiai eredmények között jellemző. Ilyen eredmény született azonban passzív rács alkalmazásával, kombinálva a ingadozó szélcsatorna ventilátor sebességével [9]. A közelmúltban a leggyakoribb aktív rácsokat elsősorban Makita és Miyamoto által bevezetett forgó lapátok látták el [10]. Ezt követően egy részletesebb tanulmány leírta az aktív rács teljesítményét, és bemutatta az indukált homogén kvázi-izotróp turbulencia néhány jellemzőjét (Makita (1991)). Az aktív rács mögött lebomló turbulencia tulajdonságait (Makita [11]) összehasonlítottuk Kang és munkatársai által végzett nagyörvényü szimulációk eredményeivel. 2003 [8], és eredményeik szerint Comte-Bellot és Corrsin, 1971 [4] eredményeinek felülvizsgálata szükséges. Larssen és Devenport elkészítette ezt a rácsfajtát, amely valószínúleg a legnagyobb eddig kifejlesztett rács, amely egyesíti a turbulencia rácsok fejlödésének különböző szakaszait [12].

\subsection{Hibrid szolár rendszerek}

Az emberi népesség növekedése és az ezzel járó ipari forradalom folyamatosan növekvő energiaigényhez vezet, ahol a fosszilis üzemanyagok jelentik a fó energiaforrást, amelyet az áramtermelés miatti hatalmas szén-dioxid-kibocsátás jellemez. Számos megvalósíthatósági tanulmány végzett annak meghatározására, hogy melyek a környezetbarát rendszerek (megújuló energiaforrások), amelyek hosszú élettartamúak, nagy megbízhatósággal és hatékonysággal bírnak. Ezeket a rendszereket a foszszilis tüzelőanyagok rendszerének alternatívájaként választották [17], alternatív energiát alkalmazó források, mint nem hagyományos források, például szélenergia, vízenergia, biogáz, biomassza energia 
és napelem. A növekvő villamosenergia-kereslet okaként egyéb okok, például a növekvő globális felmelegedés, valamint az olajár és a gázkibocsátás ingadozása [18]. Ebben az összefüggésben olyan új környezetbarát rendszereket kell használni, amelyek a hibrid rendszert életképes alternatívának tekintik, ahol a hibrid rendszer alkalmas arra, hogy kielégítse a fogyasztók energiaigényét elszigetelt területeken [19]. A hibrid rendszer két vagy több olyan rendszer kombinációja, amely az energiaforrásoktól függően eredményez hatékony és stabil energiát szolgáltathat. Sok tudós megállapította, hogy a napenergia / geotermikus rendszer megfelelő lehetőséget jelent a stabil energiaforrás elérésére, mivel jó tulajdonságával lehetővé teszi a károsanyag kibocsátás nélküli müködést és az egyensúlyi állapotot. A napból nyert felesleges hőenergia átalakítása és az elraktározott egységek segítségével az éjszaka folyamán a szükséges energiaigény kielégítésére lehetőséget ad [20]. A hibrid nap- és szélenergiát előnyben részesítik, különösen a vidéki térségekben, ahol nincs nagy előnye a hálózati ellátásnak a villamos energia iránti kereslet növekedése miatt, ami a megújuló energia felé vezet. A nap- és szélenergiák jellemzői szakaszosak, ezért a hibrid rendszerek elfogadása jó lehetőséget jelent az energiaellátás biztosításához, még annak egyik forrásának hiányában is, mint a nap vagy a szél, és ezáltal elérni a maximális kapacitást az előnyök kihasználásával [21]. Kombinálja a hagyományos és a hibrid szolár / dízel rendszer által képviselt környezetbarát rendszert, amelyet megoldásokként alkalmaznak olyan területeken, ahol nincs hálózat, ahol a kiválasztott hibrid szolár / dízel akkumulátor rendszer megbízható, megfelelő hatékonysággal rendelkezik, hogy jelentős kimaradás nélkül táplálja az energiahálózatot, bár a mérgező károsanyag kibocsátás megmarad [22], a napsugárzást tiszta energiaforrásként alkalmazva, amely más típusú rendszerrel együtt használ, akár hibridként, akár külön. A közelmúltban általában hibrid fotovoltaikus / termikus kollektort használnak, és ez a rendszer egyszerre biztosít elektromos és hőenergiát. A kombinált PV / termikus rendszer fö célja a PV rendszer általános hatékonyságának növelése a napelemek hütésével a napkollektorok csövei között, amelyek (víz, levegő) vagy más folyadék közeget tartalmaznak. Így a napelemek hőmérsékletének csökkentésével a PV jó hatásfokkal müködik, hozzáadva a hőenergiát, amely a napsugárzás és a napelemek hőnyeresége miatt növekszik [23]. Magyarországon az atomenergia és a szén túlsúlya az import villamos energián kívüli villamos energiatermelésben. A közelmúltban Magyarország támogatni kívánja lehetőségeit az energia állandósága terén azáltal, hogy olyan megújuló energiaforrásokat alkalmaz, amelyek tiszta, biztonságos és gazdaságosnak minősülnek, hogy megfeleljenek az elektromos energia és a fütés igényeinek stb. [24]. Müszaki és gazdasági tanulmányokat végeztek a fotovoltaikus rendszer magyarországi viszonyok közötti különböző felhasználására, $50 \mathrm{~kW}$ és $500 \mathrm{~kW}$ közötti teljesítményü helyi önkormányzatok és ipari szektorok számára. Az eredmények azt mutatják, hogy a napenergia területén a beruházás gazdaságilag és technikailag jó volt, alacsony megtérülési idővel, kevesebb, mint 10 év. [25].

\section{Turbulencia mérés}

A kialakuló sebesség profil vizsgálatára került sor áramlási irányban a turbulencia generátor (szalagrács) egy nyomás alatti kis sebességü nyitott végü szélcsatornában. A mérési zóna keresztmetszete 400x400 mm négyzet alakú. A levegő sebessége megváltoztatható az axiális ventilátor sebességének megváltoztatásával. A maximális sebesség az aktuális beállítással $6 \mathrm{~m} / \mathrm{s}$ körül van.

A mérés a szélcsatorna végén helyezkedik el, amint az az 1. ábrán látható. A szalagrácstól távolodva az áramlás turbulens mozgási energiája megváltoztatható a feszítők lazításával vagy meghúzásával, valamint a szalagok szögének megváltoztatásával (szalagvezetők segítségével). A szalagok rugóacélból készülnek, vastagságuk $0,5 \mathrm{~mm}$, szélességük $5 \mathrm{~mm}$. 


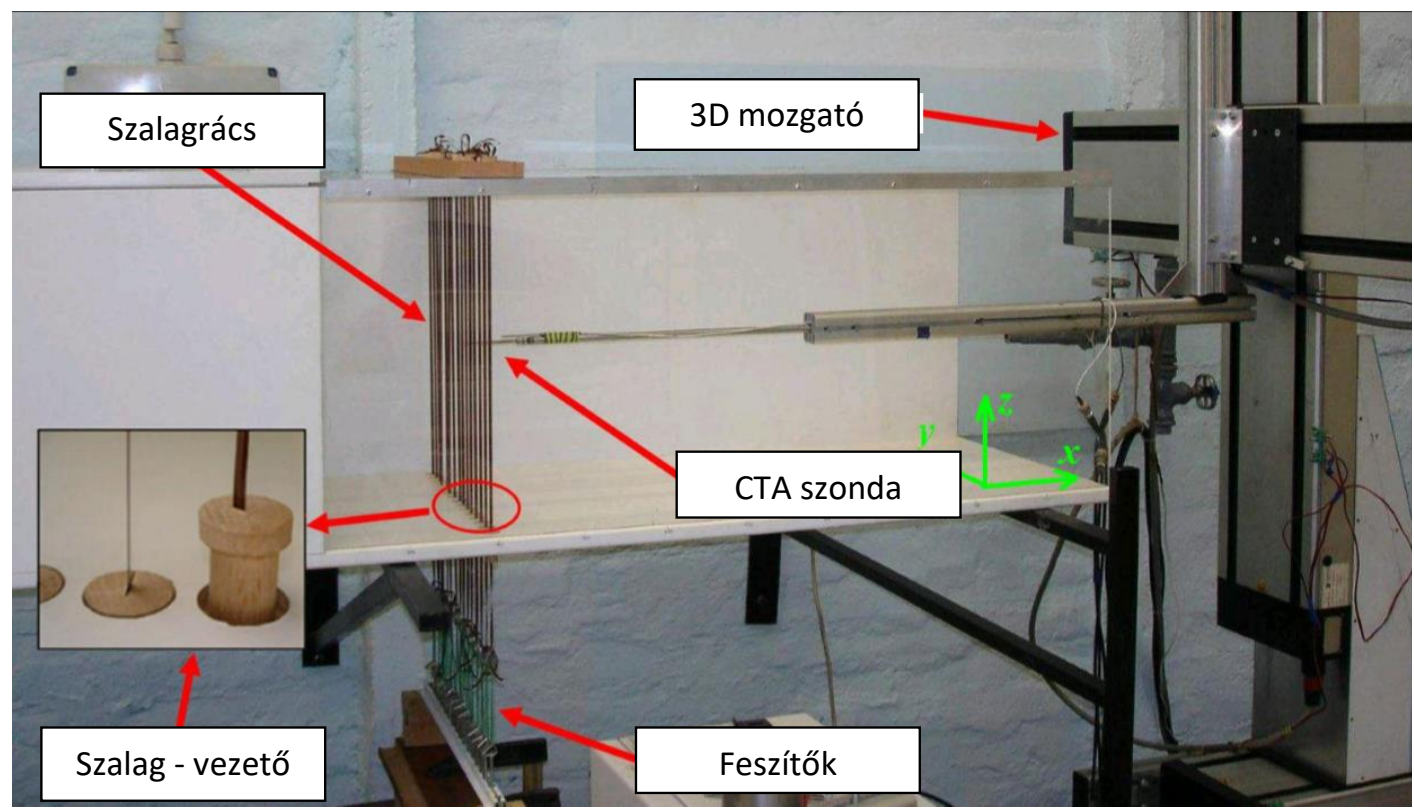

\section{1. ábra. Nyitott szélcsatorna}

Kétdimenziós CTA (Constant Temperature Anemometry) szondák segítségével két sebességkomponens rögzíthetö egyszerre nagyfrekvenciás mintavétellel [13-16]. Mivel az eredményeket egy vonal mentén normalizáljuk, a szonda egyszerü 90 fokos elfordításával meg lehet mérni a maradék sebességkomponenst. Noha nem egyidejüleg, a sebességkomponenseknek elméletileg megbízhatóan kell ábrázolniuk a sebességmezőt; és mivel mindkét esetben meg fogjuk mérni az $u$ értéket, $v$ és $w$ normalizálható az adatfeldolgozás során.

A vizsgálat fő jelentősége a falhoz közeli sebességingadozások mérése különböző Reynoldsszámok és különböző turbulencia-intenzitású áramlások esetén. Az első méréseknél a mintavételi frekvenciát 4 kHz-re választottuk, bár ez a szám valószínüleg a jövőben emelkedni fog. A szondának van egy beépített hőmérsékletmérő pontja, amely minden lépésben rögzíti a környezeti hőmérsékletet. A szonda lehetővé teszi a sebességprofil meghatározását a sebességhatárok széles skáláján, a viszonylag alacsony sebességtől a nagy sebességig $(0,2 \mathrm{~m} / \mathrm{s}$-tól 0,8 Mach körüli értékig).

Az előzetes teszteket maximális ventilátorsebességgel, $4 \mathrm{kHz}$-es mintavételi frekvenciával és 80 000/perc mintaszámmal végezték. A CTA szondát a szélcsatorna alsó falától ( $3 \mathrm{~mm}) 0,5 \mathrm{~mm}$-es lépésekben felfelé mozgattuk a szimmetriatengelyig. A vizsgálatot ezért egy függőleges vonal mentén hajtottuk végre, amely $500 \mathrm{~mm}$-re volt a turbulencia rácstól lefelé (20 M körül, ahol M az egyes szalagok közötti távolság). A 2. ábra az áramlás energiaeloszlását mutatja. Az áramlás átlagos sebessége $4,735 \mathrm{~m} / \mathrm{s}$. Mivel ekvivalens átméröje $0,4514 \mathrm{~m}$, kinematikai viszkozitása 15,06-10-6 m²/s, a Reynolds-szám ebben az esetben 141924.

Az eredmények azt mutatják, hogy a szalag turbulencia rács meglehetősen inhomogén turbulencia mezőt generál; az ingadozások (a diagramokon függőleges rezgéseknek tekinthetők) akkor következnek be, amikor egyre távolabb kerülünk a faltól. Ennek oka, hogy a turbulencia rács fent és alul rögzítve van, ezért a rezgések amplitúdója növekszik, ha egyre távolabb kerülünk a faltól és elméletileg a csatorna közepén csúcsosodik ki. 


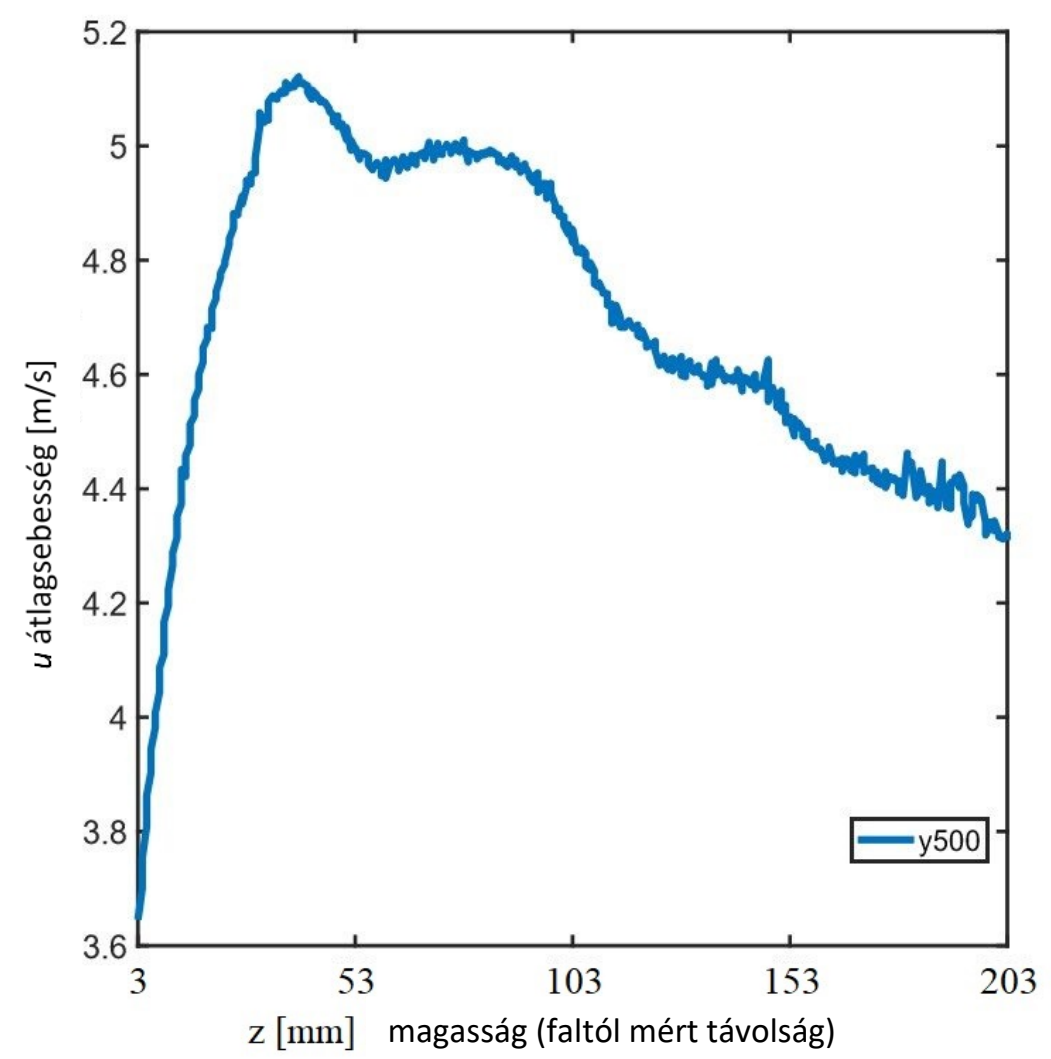

2. ábra. Az ,u” átlagos sebesség a faltól való távolság függvényében

\section{Hibrid szolár rendszer}

A fotovoltaikus rendszer elfogadása az elmúlt években gyorsan növekedett, a tiszta villamosenergiatermelés különböző kapacitásaival és csökkentve a hagyományos energiától való függőséget. A fotovoltaikus rendszernek hátránya, amikor a hőmérséklet olyan nagy, hogy hatással van a napelemekre, ami a PV panel hatékonyságának csökkenéséhez vezet, és néha a napelemek tönkremeneteléhez vezet [26].

Különböző technikákat alkalmazva, amelyek hozzájárulnak a napelemek hatékonyságának fenntartásához, ezek egyike egy hütőrendszer, amely a PV rendszert levegővel, mint hőátadó közeggel kombinálva a lemez mögött elhelyezett csatornákon keresztül hüti, a PV panelekkel érintkezve csökkenti a napelemek magas hőmérsékletét. Másrészt használható víz is magas hőteljesítményü közegként, ahol a hütőrendszer PV panel mögött helyezkedik el, amely abszorbens lemezböl áll, amelynek csövei be vannak ágyazva a PV cellák magas hőmérsékletü terébe, miközben kialakul a megfelelő hőmérsékleti tartomány. Így a PV-rendszerből származó hőnyereség miatt nagy hatékonysággal és hőenergiával nyerjen elektromos energiát [27].

A PV / termikus rendszer általános hatékonysága a PV / termikus rendszer lényegét képviseli, és ennek megfelelően sok kutató különféle technikákat dolgozott ki, amelyek növelik a rendszer hatékonyságát, miközben maximalizálják a kimeneti teljesítményt. Ezért a PV / termikus teljesítményének javítása érdekében egy új technikát alkalmaztak, amely PCM (fázis átalakuló anyag)-et adtak hozzá a napkollektorokhoz, amelyek jó előnnyel rendelkeznek a hő elnyelésében és felszabadításában. A PCM 
használatával a napelemek majdnem állandó hőmérsékleten müködnek, növelve a PV panel hatásfokát. A PV-k hütésére PCM-ként használt zsírsav téglalap alakú fémbe helyezése után bordákkal látják el, amelyek elvezetik a PV panel hőnyereségét, ahol az alacsony hővezető PCM (zsírsav) hozzájárult a PV hatékonyságának javításához [28].

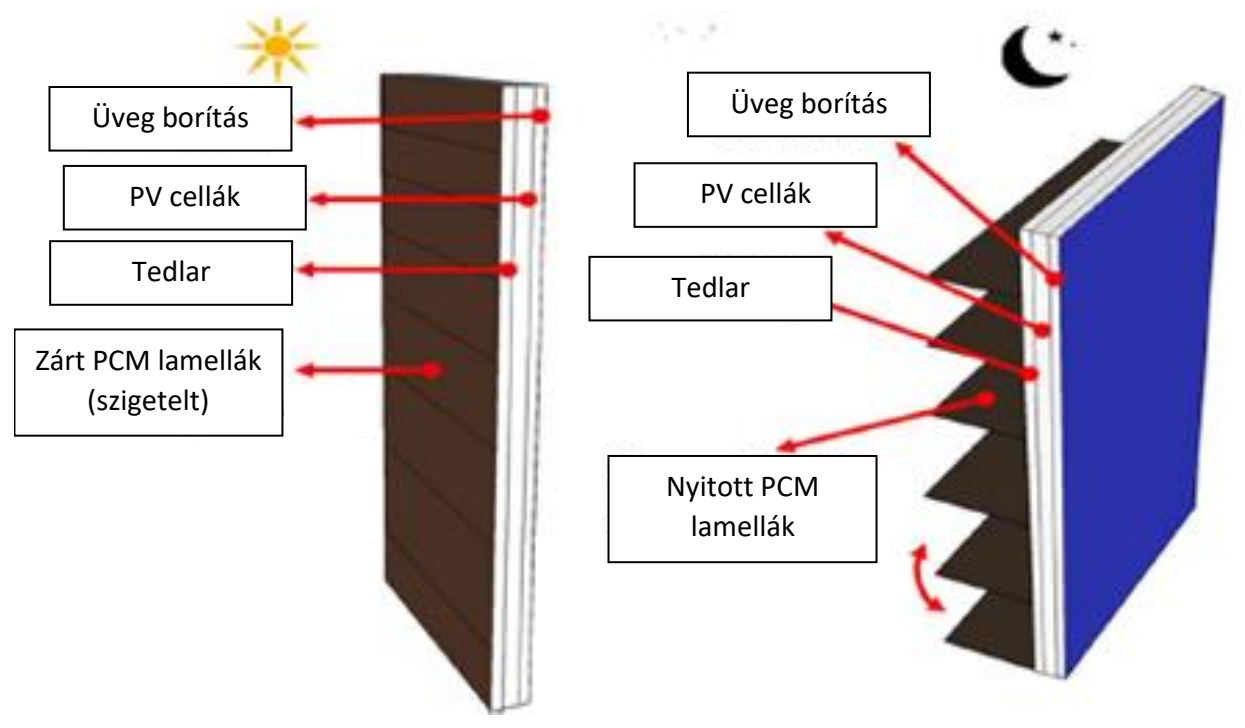

\section{3. ábra. Hibrid PV/Thermal rendszer PCM-mel}

A nanofolyadékok különböző százalékban történő keverése a folyadékkal, mint új technika, a PVvel mint hőátadó egységgel, amelynek hővezető képessége az alapfolyadékhoz képest magas, és széles körben használják a hőcserélökben, valamint a PV / T rendszerben is [29]. Jelentős az a képesség, hogy egynél több olyan technika integrálható, amely hozzájárul az általános hatékonyság növeléséhez és a rendszer teljesítményének javításához. A nanofolyadék bizonyos százalékának összekeverése a hővezető képesség növelését célzó PCM-mel, ahol a PV-modul csatlakozik a PV-panel hátulján lévő hőtároló tartályhoz, valamint a rézcsöveket tartalmazó tartályhoz. A PV panel hőmérséklete, így a tartály lehül a nanofolyadék külső hőcserélővel történő kombinálásával. A PV / termikus hőhatékonyságot az elektromos energiával és a rendszer gazdaságosságával nő, ami a jövőben ígéretesé teszi ezen technológiák együttes alkalmazását [30].

\section{4. Összefoglalás}

Átfogó szakirodalmi áttekintés után kísérleti adatok hiányát fedezték fel Reynolds feszültségek formájában a sík felületek közelében. Már kifejlesztettek egy új típusú félaktív sugár rács turbulencia generátort [16], valamint passzív szalagrácsot, amelyek jelenleg elősegítik vizsgálatainkat. Célunk, hogy folytassuk a turbulencia rácsok fejlesztését, a sík felületek közelében folyó áramlás alakulására vonatkozó vizsgálatainkkal párhuzamosan, hogy javítsuk hatókörüket. Megfigyeléseink különbözö Reynolds-számú, áramlási sebességü, relatív felületi érdességü és változó turbulencia-intenzitású légáramokra terjednek ki. Fontos meghatározni a turbulens áramlások minél több áramlási paraméterét (például a sebességingadozásokat, hosszskálákat, Reynolds-feszültségeket, Kármán energiaspektrumokat stb.) a kiterjedt adatbázis létrehozása érdekében. Az előzetes tesztek azt mutatják, hogy a rendszer müködik, és felhasználhatjuk a légáramlás turbulens tulajdonságainak mérésére. A jövőben azonban 
tervezzük a rendszer fejlesztését, hogy alkalmassá váljon a falhoz közelebb eső sebességprofilok $(0 \div 3 \mathrm{~mm}$ közötti) vizsgálatára, és homogénebb turbulencia eloszlást érjünk el.

A különböző megújuló energiaforrások felhasználása, amelyek biztosítják az energiaellátás fenntarthatóságát, folyamatosan fejlődnek a terhelési igényeknek megfelelően. A hagyományos energia alternatív erőforrásaként megbízhatóan hatékony napenergia-rendszerek elfogadása hozzájárul a károsanyag kibocsátás és a hagyományos energia csökkentéséhez. Ez a cikk egy új típusú hibrid rendszer tanulmányozásával igyekszik azonosítani az általános alkalmazásokra alkalmas hibrid rendszert. A hibrid szolár PV / termikus rendszer használatával a rendszer általános hatékonyságának növelése érdekében, a PCM, a nano folyadék vagy a PCM-nano folyadék keverékének felhasználásával a PV panel hütése révén, a napelemek hatékonyságának fenntartása és a növekedés érdekében höenergia termelése is megtörténik. A hibrid szolár / termikus rendszer használata hatékonynak bizonyul a szükséges villamosenergia-terhelések kielégítésére, és jó kapacitással rendelkezik ahhoz, hogy egyszerre biztosítson hőenergiát károsanyag kibocsátás nélkül.

\section{Köszönetnyilvánítás}

A cikkben ismertetett kutató munka az EFOP-3.6.1-16-2016-00011 jelü „Fiatalodó és Megújuló Egyetem - Innovatív Tudásváros - a Miskolci Egyetem intelligens szakosodást szolgáló intézményi fejlesztése" projekt részeként - a Széchenyi 2020 keretében - az Európai Unió támogatásával, az Európai Szociális Alap társfinanszírozásával valósul meg.

\section{Irodalom}

[1] Hak, M. G., Corrsin, S.: Measurements of the nearly isotropic turbulence behind a uniform jet grid, Journal of Fluid Mechanics, 62 (01) (1974) pp. 115-143.

https://doi.org/10.1017/S0022112074000607

[2] Simmons, L. F. G., Salter, C.: Experimental investigation and analysis of the velocity variations in turbulent flow, Proceedings of the Royal Society of London. Series A, Containing Papers of a Mathematical and Physical Character, (1934) pp. 212-234. https://doi.org/10.1098/rspa.1934.0091

[3] Comte-Bellot, G., Corrsin, S.: The use of a contraction to improve the isotropy of gridgenerated turbulence, Journal of Fluid Mechanics, 25 (04) (1966) pp. 657-682. https://doi.org/10.1017/S0022112066000338

[4] Comte-Bellot, G., Corrsin, S.: Simple eulerian time correlation of fulland narrow-band velocity signals in grid-generated, isotropic turbulence, Journal of Fluid Mechanics, 48 (02) (1971) pp. 273-337. https://doi.org/10.1017/S0022112071001599

[5] Kurian, T., Fransson, J. H. M.: Grid-generated turbulence revisited, Fluid dynamics research, 41 (2) (2009) pp. 021-403. https://doi.org/10.1088/0169-5983/41/2/021403

[6] Ling, S. C., Wan, C. A.: Decay of isotropic turbulence generated by a mechanically agitated grid, Physics of Fluids (1958-1988), 15(8) (1972) pp. 1363-1369.

https://doi.org/10.1063/1.1694093

[7] Ozono, S., Miyagi, H., Wada, K.: Turbulence generated in active grid mode using a multi-fan wind tunnel, Journal of Fluid Science and Technology, 2 (3) (2007) pp. 643-654. https://doi.org/10.1299/jfst.2.643

[8] Kang, H. S., Chester, S., Meneveau, C.: Decaying turbulence in an active-grid-generated flow and comparisons with large-eddy simulation, Journal of Fluid Mechanics, 480 (94) (2003) pp.129-160. https://doi.org/10.1017/S0022112002003579 
[9] Bordás, R., Hagemeier, T., Wunderlich, B., Thévenin, D.: Droplet collisions and interaction with the turbulent flow within a two-phase wind tunnel, Physics of Fluids (1994-present), 23 (8) (2011) pp. 085-105. https://doi.org/10.1063/1.3609275

[10] Makita, H., Miyamoto, S.: Generation of high intensity turbulence and control of its structure in a low speed wind tunnel, In Proceedings of 2nd Asian congress on fluid mechanics, (1983) pp. 101-106.

[11] Hideharu, M.: Realization of a large-scale turbulence field in a small wind tunnel, Fluid Dynamics Research, 8 (1-4) (1991) p. 53. https://doi.org/10.1016/0169-5983(91)90030-M

[12] Larssen, V. J., Devenport, J. W.: On the generation of large-scale homogeneous turbulence, Experiments in fluids, 50 (5) (2011) pp. 1207-1223.

https://doi.org/10.1007/s00348-010-0974-1

[13] Laufer, J.: Investigation of turbulent flow in a two dimensional channel, National Advisory Committee for Aeronautics, 1951.

[14] Laufer, J.: The structure of turbulence in fully developed pipe flow, National Bureau of Standards, 1952.

[15] Nikuradse, J.: Strömungsgesetze in rauen Rohren, Forschung auf dem Gebiete des Ingenieurwesens, 1933.

[16] Szaszák, N., Roloff, C., Bordás, R., Bencs, P., Szabó, Sz., Thévenin, D.: A novel type of semiactive jet turbulence grid, Heliyon 4, 2018. https://doi.org/10.1016/j.heliyon.2018.e01026

[17] Ramli, M. A. M., Hiendro, A., Twah, S.: Economic analysis of PV/diesel hybrid system with flywheel energy storage, Renewable Energy, 78 (2015) pp. 398-405.

https://doi.org/10.1016/j.renene.2015.01.026

[18] Gupta, T., Namekar, S.: Harmonic analysis and suppression in hybrid wind \& PV solar system, International Conference on Electrical, Electronics, https://doi.org/10.1063/1.5031987

[19] Sawle, Y., Gupta, S. C., Bohre, A. K.: PV-wind hybrid system, A review with case study, Cogent Engineering, (2016) 3, https://doi.org/10.1080/23311916.2016.1189305

[20] Al-Hamed, K. H. M., Dincer, I.: Investigation of a concentrated solar-geothermal integrated system with a combined ejector-absorption refrigeration cycle for a small community, International Journal of Refrigeration, 106 (2019) pp. 407-426. https://doi.org/10.1016/j.ijrefrig.2019.06.026

[21] Ka, R., Kulkarnib, D., Ananthapadmanabha, T.: Modeling and simulation of solar PV and DFIG based wind hybrid system, Procedia Technology, 21 (2015) pp. 667-675. https://doi.org/10.1016/j.protcy.2015.10.080

[22] Madziga, M. I. D., Rahil, A., Mansoor, I. R.: Comparison between three off-grid hybrid systems (solar photovoltaic, diesel generator and battery storage system) for electrification for Gwakwani village, South Africa, Environments (2018) pp. 5-57.

https://doi.org/10.3390/environments5050057

[23] El-Samie, M. M. A., Ju, X., Zhang, Z., Adam, S. A., Pan, X., Xu, C.: Three-dimensional numerical investigation of a hybrid low concentrated photovoltaic/thermal system, Energy, https://doi.org/10.1016/j.energy.2019.116436

[24] Kiss, V. M., Hetesi, Zs., Kiss, T.: Issues and solutions relating to Hungary's electricity system, Energy 116 (2016) pp. 329-340. https://doi.org/10.1016/j.energy.2016.09.121

[25] Zsiborács, H., Hegedüsné Baranyai, N., Csányi, Sz., Vincze, A., Pintér, G.: Economic analysis of grid-connected PV system regulations, A Hungarian Case Study, Electronics, (2019) https://doi.org/10.3390/electronics8020149 
[26] Luthander, R., Widén, J., Nilsson, D., Palm, J.: Photovoltaic self-consumption in buildings, A review, Applied Energy, 142 (2015) pp. 80-94. https://doi.org/10.1016/j.apenergy.2014.12.028

[27] Maatallah, T., Zachariah, R., Galla, F., Al-Amria: Exergo-economic analysis of a serpentine flow type water based photovoltaic thermal system with phase change material (PVTPCM/water), Solar Energy, 193 (2019) pp. 195-204. https://doi.org/10.1016/j.solener.2019.09.063

[28] Xu, H., Zhang, C., Wang, N., Qu, Z., Zhang, S.: Experimental study on the performance of a solar photovoltaic/thermal system combined with phase change material, China, Solar Energy, 198 (2020) pp. 202-211. https://doi.org/10.1016/j.solener.2020.01.064

[29] Al-Waeli, A. H. A., Chaichan, M. T., Kazem, H. A., Sopian, K.: Evaluation and analysis of nanofluid and surfactant impact on photovoltaic-thermal systems, Case Studies in Thermal Engineering, https://doi.org/10.1016/j.csite.2019.100392

[30] Al-Waeli, A. H. A., Kazem, H. A., Chaichan, M. T., Sopian, K.: Experimental investigation of using nano-PCM/nanofluid on a photovoltaic thermal system (PVT), Technical and Economic Study, Thermal Science and Engineering Progress, https://doi.org/10.1016/j.tsep.2019.04.002 